\title{
COVID-19 AND FERTILITY - BABY BOOM OR BUST?
}

\section{COVID-19 A PŁODNOŚĆ - BABY BOOM CZY NIŻ?}

\author{
Harpreet Singh Dhillon ${ }^{1(B, C)}$, Shibu Sasidharan ${ }^{2(A)}$ \\ ${ }^{1}$ Department of Psychiatry, 166 Military Hospital, Jammu, India \\ ${ }^{2}$ Department of Anesthesiology and Critical Care, Level III IFH, United Nations Organization Stabilization Mission \\ in the Democratic Republic of the Congo, Goma, the Democratic Republic of the Congo
}

Authors' contribution Wkład autorów: A. Study design/planning zaplanowanie badań B. Data collection/entry zebranie danych

C. Data analysis/statistics dane - analiza i statystyki D. Data interpretation interpretacja danych E. Preparation of manuscript przygotowanie artykułu F. Literature analysis/search wyszukiwanie i analiza literatury G. Funds collection zebranie funduszy
Tables: 1

Figures: 0

References: 14

Submitted: 2021 Jan 5

Accepted: 2021 Jan 14

\section{Dear Editor,}

Coronavirus disease 2019 (COVID-19) has adversely affected every segment of the population in unimaginable ways. Consequences of natural disasters (deaths) are generally followed by decline in birth within a year; whereas in a longer time frame following the event, patterns of increasing fertility are generally seen [1]. However, during this pandemic, owing to the strict lockdown, couples have more time to spend with each other, and are thus assumed to procreate more, leading to a phenomenon called 'baby boom'. This however is currently not backed by evidence despite an 'infodemic' on COVID-19 and hence this perspective [2]. The correlation of COVID-19 with fertility may have different effects depending on socio-economic status, cultural beliefs, population density and age distribution. The World Bank classifies countries into income groups as low-, lower middle-, upper middle-, and high-income categories [3]. The spectrum of response to lockdown is starkly different in all these groups (Table 1).

\section{Male fertility \& COVID-19}

The role of angiotensin converting enzymes 2 (ACE2) receptors in pathogenesis of COVID-19 is well documented. SARS-COV2 virus binds to ACE2 receptors and facilitates cell entry and replication [5]. Therefore, cells with a high level of ACE2 expression are likely to be targeted and damaged by the virus [5]. Multiple studies detected a high ACE2 expression level in testicular cells (mainly in seminiferous duct cells, spermatogonia, Leydig cell and Sertoli cells) [5-7]. The results of these studies, concludes that the testis could be a potential target for direct damage by the virus, though there is no conclusive answer yet if it can cause infertility. A study has mentioned orchitis as a recognized complication of SARS [8]. Testicular damage caused by SARS-COV2 virus can be by either effect through ACE2 receptors or secondary to immunological and inflammatory response. So far there is no definitive answer whether a follow-up of reproductive function of recovered male patients is required [9].

\section{Implications and recommendations}

\section{Lower \& Middle Income Countries (LMIC)}

The fertility and eventually the demography in low-income countries is driven by the idea that more hands will earn more. This leads to child labor even at the cost of sacrificing their education and bringing down their quality of life in the long term. There is also a deeply embedded notion that more children provide a better 
Table 1. Spectrum and effect of lockdown on fertility

\begin{tabular}{|c|c|c|c|c|c|}
\hline $\begin{array}{l}\text { Country } \\
\text { category }\end{array}$ & $\begin{array}{l}\text { Area of } \\
\text { residence }\end{array}$ & Issues & Effect & Consequence & $\begin{array}{l}\text { Effect on } \\
\text { fertility }\end{array}$ \\
\hline \multirow{6}{*}{$\begin{array}{l}\text { Lower \& } \\
\text { Middle Income } \\
\text { Countries } \\
\text { (LMIC) }\end{array}$} & \multirow{3}{*}{ Urban } & $\begin{array}{l}\text { Loss of jobs and } \\
\text { economic instability }\end{array}$ & High & $\begin{array}{l}\text { More time at home with partner } \\
\text { Increased financial burden/strain } \\
\text { due to job affected }\end{array}$ & $\begin{array}{l}\text { Mixed } \\
\text { response }\end{array}$ \\
\hline & & $\begin{array}{l}\text { Availability of } \\
\text { contraception }\end{array}$ & Moderate & Underutilization & $\begin{array}{c}\text { Increased } \\
\text { fertility }\end{array}$ \\
\hline & & $\begin{array}{l}\text { Family planning } \\
\text { services [4] }\end{array}$ & Moderate & $\begin{array}{l}\text { Suboptimal family planning } \\
\text { services }\end{array}$ & $\begin{array}{c}\text { Increased } \\
\text { fertility }\end{array}$ \\
\hline & \multirow{3}{*}{ Rural } & $\begin{array}{l}\text { Loss of jobs and } \\
\text { economic instability }\end{array}$ & High & $\begin{array}{l}\text { More time at home with partner. } \\
\text { Lesser education and awareness. }\end{array}$ & $\begin{array}{c}\text { Increased } \\
\text { fertility }\end{array}$ \\
\hline & & $\begin{array}{l}\text { Availability of } \\
\text { contraception }\end{array}$ & Low & No contraception & $\begin{array}{c}\text { Increased } \\
\text { fertility }\end{array}$ \\
\hline & & $\begin{array}{c}\text { Family planning } \\
\text { services }\end{array}$ & Rare & Not existent in most areas & $\begin{array}{l}\text { Increased } \\
\text { fertility }\end{array}$ \\
\hline \multirow{3}{*}{$\begin{array}{l}\text { High Income } \\
\text { Countries (HIC) }\end{array}$} & \multirow{3}{*}{ Urban } & $\begin{array}{l}\text { Loss of jobs and } \\
\text { economic instability }\end{array}$ & High & $\begin{array}{l}\text { More time at home with partner } \\
\text { Increased financial burden/strain } \\
\text { due to job affected }\end{array}$ & $\begin{array}{l}\text { Reduced } \\
\text { fertility }\end{array}$ \\
\hline & & $\begin{array}{l}\text { Availability of } \\
\text { contraception }\end{array}$ & High & Better access & $\begin{array}{l}\text { Reduced } \\
\text { fertility }\end{array}$ \\
\hline & & $\begin{array}{l}\text { Family planning } \\
\text { services }\end{array}$ & Hampered & $\begin{array}{l}\text { No family planning services to } \\
\text { plan pregnancy }\end{array}$ & $\begin{array}{l}\text { Reduced } \\
\text { fertility }\end{array}$ \\
\hline
\end{tabular}

sense of security for parents in old age in low-income countries where old age pension service is not guaranteed as compared to high-income countries. It is as such very difficult to impart awareness and bring about a change in the attitude in the generally uneducated masses in low income countries, which has been further compounded by the current pandemic by skyrocketing unemployment and severely crippling the family planning and contraceptive programmes leading to the direct rise in chances of pregnancy [10].

Along with the increased rates, there are additional risks to the growing foetus, majorly the risk of contracting COVID-19 by the foetus, but also compromised antenatal care (supplementation, anomaly screening, vaccination etc.) caused by a greater load on maternal and child healthcare services in the times of COVID-19 when already specialists from all specialties are being recruited to work in COVID-19 wards like it was seen in the recent West African Ebola crisis [11]. This can further damage the already resource-limited health care sector in LMIC by putting additional demands on personal protective equipment, quarantine facilities etc. It will also have an impact on the economic resources with increased demand for food production, housing, employment sources and community health, thus impeding the economic growth.

Economic hardship and poverty do not necessarily make a reversal of high fertility in the LMIC. For these countries, policies and decisions affecting, directly and indirectly, the world's demographics need to come to fore.

\section{Recommendations}

1. Special emphasis needs to be given to the constant monitoring especially in underprivileged groups to ensure sustained access to family planning and contraceptive measures, maybe with a reduced frequency.

2. Financial packages to address poverty and easy creditto revive small businesses to address unemployment can be the key.

3. In conclusion, creating job opportunities, providing social safety networking, relief packages, virtual training programs, and compassionate counselling may reduce fertility rate across these countries.

\section{High-income countries (HIC)}

The fertility rate in HIC is lower compared to LMIC and is continuously declining for a variety of social and economic reasons. Aging population, lack of commitment and relationship, delayed marriages, personal choices and lack of social support are a few contributors. This pandemic has only amplified all these factors with the addition of economic crunch to the list. The lockdown has further impacted women undergoing assisted reproductive technology (ART) by breaking the cyclical treatment. The closing down of schools during lockdown has also shifted the till now outsourced support onto the parents, burdening them with childcare and household 
work, to which most of them are not accustomed to. This could lead to potentially reduced desire and voluntary childlessness. This progressive fall in fertility in short term would further escalate the aging population in HIC. Similar demographic changes were noticed post the Great Recession in 2008, with overall decline in fertility especially in HIC [12].

\section{Recommendations}

1. The fertility rate can be boosted by sensitizing about better gender equality in child care and other domestic work [13-14].

2. At national level, there is a need to concoct smart strategic economic policies aiming at long-term growth and effectively dealing with prolonged lockdown. The current economic global depression can be addressed by providing relief packages like easy credit facility at nil/low interest rates, easy and prolonged instalments, discounts for revival of small businesses etc.

\section{References:}

1. Nandi A, Mazumdar S, Behrman JR. The effect of natural disaster on fertility, birth spacing, and child sex ratio: evidence from a major earthquake in India. SSRN Electron J. 2018; 31: 267. https://doi.org/10.1007/s00148-017-0659-7

2. Sasidharan S, Singh DH, Vijay S, Manalikuzhiyil B. COVID-19: Pan (info) demic. Turkish Journal of Anaesthesiology and Reanimation. 2020 Dec;48(6):438. https://dx.doi.org/10.5152\%2FTJAR.2020.1008

3. World Bank. How does the World Bank classify countries? - World Bank Data Help Desk [Internet]. Washington, DC: World Bank [cited 2020 Jul 31]. Available from: https:/datahelpdesk.worldbank.org/ knowledgebase/articles/378834-how-does-the-world-bank-classify-countries

4. U.S. Department of Health \& Human Services. Family planning services [Internet]. Washington, DC: 3. U.S. Department of Health \& Human Services [cited 2020 Jul 31]. Available from: https://www.hhs.gov/opa/ guidelines/clinical-guidelines/quality-family-planning/qfp-services/family-planning-services-text-only/ index.html

5. Fan C, Li K, Ding Y, Lu WL, Wang J. ACE2 expression in kidney and testis may cause kidney and testis damage after 2019-nCoV infection. medRxiv. 2020 Feb 13. https://doi.org/10.1101/2020.02.12.20022418

6. Shen Q, Xiao X, Aierken A, Yue W, Wu X, Liao M, et al. The ACE2 expression in Sertoli cells and germ cells may cause male reproductive disorder after SARS-CoV-2 infection. J Cell Mol Med. 2020; 24(16): 9472-9477. http://doi.wiley.com/10.1111/jcmm.15541

7. Wang Z, Xu X. scRNA-seq profiling of human testes reveals the presence of the ACE2 receptor, a target for SARS-CoV-2 infection in spermatogonia, leydig and sertoli cells. Cells. 2020; 9(4): 920. https://doi.org/10.3390/cells9040920

8. Xu J, Qi L, Chi X, Yang J, Wei X, Gong E, et al. Orchitis: a complication of severe acute respiratory syndrome (SARS). Biol Reprod. 2006; 74(2): 410-416. https://doi.org/10.1095/biolreprod.105.044776

9. Abobaker A, Raba AA. Does COVID-19 affect male fertility?. World Journal of Urology. 2020. https://doi.org/10.1007/s00345-020-03208-w

10. Sasidharan S, Dhillon HS. Ebola, COVID-19 and Africa: What we expected and what we got. Developing world bioethics. 2020 Sep 20.https://doi.org/10.1111/dewb.12292

11. Sochas L, Channon AA, Nam S. Counting indirect crisis-related deaths in the context of a low-resilience health system: the case of maternal and neonatal health during the Ebola epidemic in Sierra Leone. Health Policy and Planning. 2017; 32(Suppl. 3): iii32-iii39. https://doi.org/10.1093/heapol/czx108

12. Goldscheider F, Bernhardt E, Lappegård T. The gender revolution: a framework for understanding changing family and demographic behavior. Popul Dev Rev. 2015; 41(2): 207-239. https://doi.org/10.1111/j.1728-4457.2015.00045.x

13. Sobotka T, Skirbekk V, Philipov D. Economic recession and fertility in the developed world. Population and Development Review. 2011; 37(2): 267-306. https://doi.org/10.1111/j.1728-4457.2011.00411.x

14. Esping-Andersen G, Billari FC. Re-theorizing family demographics. Popul Dev Rev. 2015; 41(1): 1-31. https://doi.org/10.1111/j.1728-4457.2015.00024.x 